\title{
A suspected viral rash in pregnancy
}

\author{
Jack Carruthers honorary clinical research fellow ${ }^{1}$, Alison Holmes professor of infectious diseases ${ }^{2}$, \\ Azeem Majeed professor of primary care ${ }^{1}$
}

${ }^{1}$ Department of Primary Care and Public Health, Imperial College London, London, UK; ${ }^{2}$ Department of Medicine, Imperial College London, London, UK

A pregnant woman at 12 weeks' gestation seeks help for a red rash covering her back and chest. She is worried that the rash might be caused by a virus. She is originally from Bangladesh and is unsure about her vaccination history.

Viral exanthema can cause rash in a pregnant woman and should be considered even in countries that have comprehensive vaccination programmes. In the UK, for example, three cases of congenital rubella syndrome have been notified in recent years in women born outside the UK. ${ }^{1}$ This article focuses on viral rashes. For a more general overview of rash in pregnancy, see the review by Vaughan-Jones et al. ${ }^{2}$

Vaccination coverage for viral infections varies globally. The World Health Organization estimates that adult varicella immunity is greater than $95 \%$ in the US but only $75 \%$ in India. ${ }^{3}$ Similarly, global measles and rubella immunisation coverage is only $85 \%$ and $44 \%$, respectively. ${ }^{4}$

These infections have consequences for mother and fetus. Measles and rubella can cause intrauterine death. Intrauterine infection with rubella can lead to congenital rubella syndrome in the liveborn baby, characterised by deafness, eye abnormalities, congenital heart disease, and learning disability. ${ }^{56}$ Meanwhile, the current Zika virus epidemic has garnered international attention for its link to microcephaly and birth defects.

\section{What you should cover \\ History}

Ask about

- Location of the rash; speed, and date of onset.

- Associated symptoms: fever, sore throat, and malaise suggest an infectious cause. Itching is usually suggestive of a non-viral cause (fig $1 \Downarrow$ ). ${ }^{8}$

- Vaccination. Has the patient received two doses of measles, mumps, and rubella vaccine? Public Health England recommends asking pregnant women for this information at their initial antenatal appointment. ${ }^{4}$ If available, review documented evidence of vaccination, as patients might not recall or be familiar with the vaccines. ${ }^{9}$ In some countries, measles and rubella vaccines are administered separately and you might need to ask about each.

- History of chickenpox or if the woman has received the vaccine.

- Antibody testing for viral infections in previous pregnancy, or if she has been vaccinated since.

- Country of origin, as vaccination coverage can vary.

- Recent travel to countries where rubella and measles are endemic. Travel to South America or the Caribbean in the last two weeks should prompt consideration of Zika virus. ${ }^{10}$

- Contact with unwell people with a rash, or with someone who has travelled to an endemic country recently.

- Sexual history for suspected Zika virus infection and HIV.?

- Duration of present pregnancy. Rubella poses the highest risk in the first trimester. Varicella can cause congenital varicella syndrome if the mother is infected in the first 20 weeks of pregnancy, or neonatal chickenpox if infected in the third trimester. ${ }^{8}$

- Drug history. If the patient is on immunosuppressants or steroids, herpes zoster may be more likely. Some medications can cause rashes and a careful drug history is warranted.

\section{Examination}

Assess general wellbeing and vital parameters. A fever should prompt consideration of infectious causes.

Examine the rash:

Is the rash vesicular or maculopapular? (fig 1, fig 2, fig 3unspecified fig ) A vesicular rash suggests varicella or herpes infection. ${ }^{11}$ If maculopapular, consider other viral infections.

Distribution of the rash: a viral exanthem is frequently found on the trunk and limbs. Varicella often follows a dermatomal 


\section{What you need to know}

- Consider country of origin in a woman presenting with a rash in pregnancy and ask for immunisation history.

- Test for measles and rubella IgM and IgG antibodies, particularly if immunisation history is not clear.

- Refer women with an active infection to the fetal medicine unit for fetal monitoring.

pattern, and herpes simplex can present with genital lesions. Appearance of the rash might vary based on skin complexion.

Associated examination findings: neck stiffness could suggest meningitis; generalised lymphadenopathy could suggest HIV.

Figure $1 \Downarrow$ presents one approach suggested for rash in pregnancy. ${ }^{8}$ Table $1 \Downarrow$ shows common viral causes of rash in pregnancy.

\section{What you should do Investigations}

If a viral exanthem is suspected, offer testing for measles, rubella, parvovirus B19, varicella, and possibly Zika virus. Take blood for serology to test for IgM and IgG antibodies. ${ }^{15}$ See box 1 for information to be included when requesting the test. Where available, polymerase chain reaction for virus isolation can be requested.

In general, a positive IgM and $\mathrm{IgG}$ demonstrate acute infection; but IgG only positivity reflects previous exposure or vaccination. $^{16}$

Counsel the woman regarding the need to screen for these conditions. A helpful phrase might be, "I' $m$ unsure of the cause of the rash at this point, but I will do $\mathrm{x}, \mathrm{y}$, and $\mathrm{z}$ to investigate what's causing it."

\section{Management}

Arrange a follow-up appointment to discuss the results and prepare the patient for possible referral to a fetal medicine unit if the results indicate active infection. ${ }^{16}{ }^{17}$

Be prepared to answer questions about potential risks to the baby, as this will likely be her main concern. Explain that positive serology in the mother may not correlate with infection in the fetus. Avoid using words like "testing the fetus" or "termination of pregnancy," as at this stage it is too early to predict the effect on the fetus from initial investigations. The fetal medicine unit might monitor with frequent ultrasonography rather than perform invasive fetal testing.

Advise avoiding contact with other pregnant women or children to minimise transmission. If Zika is suspected, advise abstaining from sexual intercourse, and to use mosquito nets and repellants. ${ }^{13}$ Most women will need MMR vaccination after the pregnancy if non-immune to measles or rubella. ${ }^{18}$

Thanks to KF for her invaluable input in the role of providing the patient's perspective. Imperial College London is grateful for support from the
Northwest London National Institute for Collaboration for Leadership in Applied Health Research and Care and the Imperial NIHR Biomedical Research Centre. The views expressed in this publication are those of the authors.

Contributors: $\mathrm{JC}$ was the lead author on the article and is the guarantor; $\mathrm{AH}$ and $\mathrm{AM}$ edited the article; KF contributed the patient's perspective and helped to review the manuscript. JC affirms that the manuscript is an honest, accurate, and transparent account of the study being reported; that no important aspects of the study have been omitted; and that any discrepancies from the study as planned (and, if relevant, registered) have been explained.

Competing interests: We have read and understood the BMJ policy on declaration of interests and declare no competing interests.

1 Banerjee A. Alert: Rubella infection in pregnancy and congenital rubella, 2016.

2 Vaughan Jones S, Ambros-Rudolph C, Nelson-Piercy C. Skin disease in pregnancy. BMJ 2014;348:g3489. doi:10.1136/bmj.g3489pmid:24895225.

3 World Health Organization. Global immunization data. Secondary Global Immunization Data 2014. http://www.who.int/immunization/monitoring surveillance/global_immunization data.pdf.

4 Plotkin SA. The history of rubella and rubella vaccination leading to elimination. Clin Infect Dis 2006;43(Suppl 3):S164-8. doi:10.1086/505950pmid:16998777

5 Banatvala JE, Brown DWG. Rubella. Lancet 2004;363:1127-37. doi:10.1016/S0140-6736 04)15897-2pmid:15064032

6 Basarab M, Bowman C, Aarons EJ, Cropley I. Zika virus. BMJ 2016;352:i1049. doi:10. 1136/bmj.i1049pmid:26921241.

7 Health Protection Agency . Guidance on viral rash in pregnancy. Secondary Guidance on viral rash in pregnancy 2011. https://www.gov.uk/government/publications/viral-rashin-pregnancy.

8 Mangtani P, Shah A, Roberts JA. Validation of influenza and pneumococcal vaccine status in adults based on self-report. Epidemiol Infect 2007;135:139-43. doi:10.1017/ S0950268806006479pmid:16740194.

9 Ahmad SS, Amin TN, Ustianowski A. Zika virus: management of infection and risk. $B M$ 2016;352:i1062. doi:10.1136/bmj.i1062pmid:26920038.

10 Miller E. Epidemiology, outcome and control of varicella-zoster infection. Rev Med Microbio 1993:4:222-30doi:10.1097/00013542-199310000-00006.

11 World Health Organization. WHO vaccine-preventable diseases: monitoring system. 2016 global summary. Secondary WHO vaccine-preventable diseases: monitoring system. 2016 global summary. 2016. http://apps.who.int/immunization_monitoring/globalsummary/

12 World Health Organization. Situation Report: Zika virus, microcephaly and Guillain-Barre syndrome. Secondary Situation Report: Zika virus, microcephaly and Guillain-Barre syndrome 2016. http://apps.who.int/iris/bitstream/10665/251462/1/zikasitrep17Nov16eng.pdf?ua $=1$.

13 Royal College of Obstetricians and Gynaecologists . Green top guideline Varicella. RCOG Guidelines.

14 Best JM, O'Shea S, Tipples G, et al. Interpretation of rubella serology in pregnancy—pitfalls and problems. BMJ 2002;325:147-8. doi:10.1136/bmj.325.7356.147pmid:12130613.

15 MacMahon E. Investigating the pregnant woman exposed to a child with a rash. BMJ 2012:344:e1790. doi:10.1136/bmj.e1790pmid:22451478.

16 Royal College of Obstetricians and Gynaecologists RCoM, Public Health England, et al. Interim RCOG/RCM/PHE/HPS clinical guidelines: Zika virus infection and pregnancy information for healthcare professionals. Secondary Interim RCOG/RCM/PHE/HPS clinical guidelines: Zika virus infection and pregnancy information for healthcare professionals 2016. www.rcog.org.uk/en/news/.

17 Schrag SJ, Arnold KE, Mohle-Boetani JC, et al. Prenatal screening for infectious diseases and opportunities for prevention. Obstet Gynecol 2003;102:753-60.pmid:14551005.

18 World Health Organization. Varicella and herpes zoster: WHO position paper, 2014

Accepted: 19012017

Published by the BMJ Publishing Group Limited. For permission to use (where not already granted under a licence) please go to http://group.bmj.com/group/rights-licensing/ permissions 


\section{Box 1: Information to be recorded on the blood test request}

- Name, age, date of birth, address

- Duration of pregnancy in weeks

- Date of onset of rash, clinical features, type and distribution of rash

- Antibody testing, if known

- Vaccine history including dates and places, if known

- Any known contacts who are unwell with rash, and dates of contact

Source: adapted from Health Protection Agency Rash Guidance Working Group, Guidance on viral rash in pregnancy; 2011

\section{Education into practice}

Do you routinely ask for vaccination history in women of child bearing age when they register with your practice?

\section{How patients were involved in the creation of this article}

We asked a pregnant woman with a rash to review the article. She said, "If there's anything that can be done to prevent things from worsening (eg, situations I should avoid, etc). that information would be quite helpful. I would likely be quite concerned about the health of the baby, and I would want the GP to be willing to answer any questions I have." We thereby inserted specific ways the GP could address concerns.

\section{Table}

\begin{tabular}{|c|c|c|c|c|c|}
\hline Infection & Epidemiology & Assessment & $\begin{array}{l}\text { Investigation in } \\
\text { primary care }\end{array}$ & Management & Possible outcomes \\
\hline Rubella & $\begin{array}{l}23 \text { cases of infection in pregnancy } \\
\text { in the UK since } 2005 \text {; three recent } \\
\text { cases of congenital rubella } \\
\text { syndrome. }{ }^{1} \text { Endemic to South East } \\
\text { Asia: Bangladesh reported } 66 \\
\text { cases of congenital rubella } \\
\text { syndrome in } 2014^{12}\end{array}$ & $\begin{array}{l}\text { Maculopapular rash in } \\
\text { pregnancy; exposure to a } \\
\text { person with a rash in the last } \\
\text { two weeks. } \\
\text { Vaccination history }\end{array}$ & $\begin{array}{l}\text { Blood for PCR and } \\
\text { serology (IgM and } \\
\text { lgG) }\end{array}$ & $\begin{array}{l}\text { Referral to fetal medicine } \\
\text { unit }\end{array}$ & $\begin{array}{l}\text { Intrauterine death. } \\
\text { Congenital rubella syndrome } \\
\text { resulting in sensorineural } \\
\text { deafness, learning difficulties, } \\
\text { congenital heart disease, and } \\
\text { other deformities in the child }\end{array}$ \\
\hline Measles & $\begin{array}{c}\text { Outbreaks throughout the world. } \\
\text { Endemic to South East Asia and } \\
\text { Africa. Former Soviet republics } \\
\text { affected }{ }^{42}\end{array}$ & $\begin{array}{l}\text { Maculopapular rash, Koplik's } \\
\text { spots on buccal mucosa, fever; } \\
\text { exposure to a person with a } \\
\text { rash in the last two weeks. } \\
\text { Vaccination history }\end{array}$ & $\begin{array}{l}\text { Blood for PCR and } \\
\text { serology (IgM and } \\
\operatorname{lgG} \text { ) }\end{array}$ & $\begin{array}{l}\text { Referral to fetal medicine } \\
\text { unit }\end{array}$ & $\begin{array}{l}\text { Preterm delivery and stillbirth. } \\
\text { Learning difficulties in live births }\end{array}$ \\
\hline Zika $^{13}$ & $\begin{array}{c}75 \text { countries report Zika virus } \\
\text { transmission. Major areas affected: } \\
\text { South America, Central America, } \\
\text { Caribbean }\end{array}$ & $\begin{array}{l}\text { Maculopapular rash, fever within } \\
\text { two weeks of travel to endemic } \\
\text { area, sexual history }\end{array}$ & $\begin{array}{l}\text { Blood for PCR and } \\
\text { serology (IgM and } \\
\text { IgG) }\end{array}$ & $\begin{array}{l}\text { Referral to fetal medicine } \\
\text { unit }\end{array}$ & $\begin{array}{l}\text { Guillain-Barré syndrome in the } \\
\text { mother } \\
\text { Microcephaly is the most } \\
\text { commonly reported abnormality } \\
\text { in the baby }\end{array}$ \\
\hline Varicella $^{14}$ & $\begin{array}{l}\text { In the UK, varicella complicates } \\
\text { three in } 1000 \text { pregnancies; more } \\
\text { common in women born outside } \\
\text { the UK }\end{array}$ & $\begin{array}{l}\text { History of exposure to } \\
\text { chickenpox; no medical history } \\
\text { of chickenpox. } \\
\text { Vesicular rash in a painful } \\
\text { dermatomal distribution }\end{array}$ & $\begin{array}{c}\text { Blood for PCR and } \\
\text { serology (IgM and } \\
\text { lgG) }\end{array}$ & $\begin{array}{l}\text { Referral to fetal medicine } \\
\text { unit. The mother may } \\
\text { need varicella intravenous } \\
\text { immunoglobulin if she } \\
\text { presents within } 10 \text { days of } \\
\text { an exposure and no rash } \\
\text { clinically; } P O \text { aciclovir can } \\
\text { be used in those with a } \\
\text { rash }\end{array}$ & $\begin{array}{l}\text { Congenital varicella: limb } \\
\text { defects, ocular and auditory } \\
\text { defects, learning difficulties. } \\
\text { Neonatal varicella: severe } \\
\text { chickenpox }\end{array}$ \\
\hline
\end{tabular}




\section{Figures}

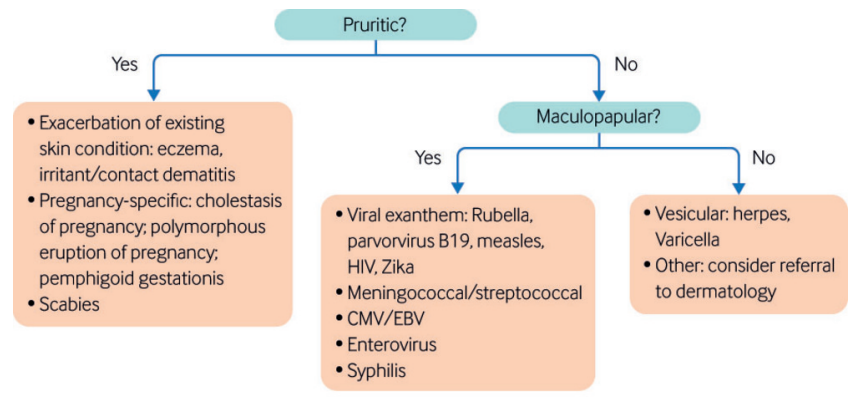

Fig 1 Diagnostic flow chart for rash in pregnancy. ${ }^{8}$ CMV: cytomegalovirus. EBV: Epstein Barr virus. Source: adapted from Health Protection Agency Rash Guidance Working Group, Guidance on viral rash in pregnancy; 2011

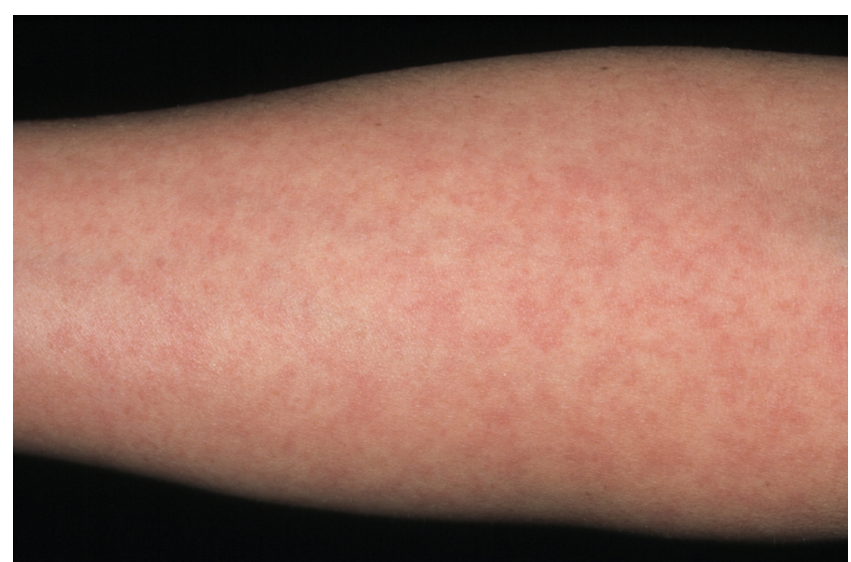

Fig 2 Rash caused by rubella virus

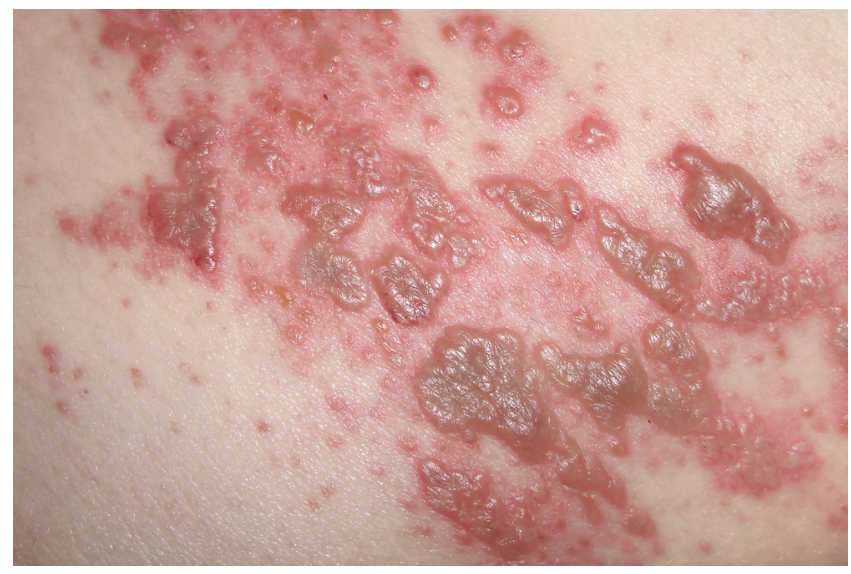

Fig 3 Varicella rash (Shingles) showing vesicles 